\title{
Groundwater vulnerability: from scientific concept to practical application
}

\author{
A. J. Witkowski ${ }^{1}$
}

Received: 14 July 2016/ Accepted: 16 July 2016/Published online: 3 August 2016

(c) The Author(s) 2016. This article is published with open access at Springerlink.com

Keywords Groundwater vulnerability · Conference · Poland

The International conference on "Groundwater Vulnerability-From Scientific Concept to Practical Application" was the second on contemporary groundwater vulnerability issues to be organised in Ustroń, Poland. In fact, it was the third IAH conference on groundwater vulnerability organised in Poland by the University of Silesia. The first on "Karst-fractured Aquifers-Vulnerability and Sustainability" was held in Katowice and Ustron in 1996. This conference was focused on techniques and strategies of investigation, protection and effective management of karst-fractured aquifers. Twenty-nine papers presented at this conference were published in a special volume of University of Silesia Scientific Works No. 1563 (Różkowski et al. 1996). The second one was also held in Ustroń in 2004. Eighty-six abstracts (including five keynote papers) of the papers presented at this conference were published in the conference abstract book (Witkowski et al. 2004). The best three papers were published in Environmental Geology (Volume 53, No. 3, November 2007) (Witkowski 2007), and the next 23 papers in Vol. 11 of IAH Selected Papers under the title "Groundwater Vulnerability Assessment and Mapping" (Witkowski et al. 2007).

This article is a part of a Topical Collection in Environmental Earth Sciences on "Groundwater Vulnerability", edited by Dr. Andrzej Witkowski.

\footnotetext{
A. J. Witkowski

andrzej.witkowski@us.edu.pl

1 University of Silesia, Katowice, Poland
}

The idea of organising the next conference in Poland in 2015 was a consequence of significant changes in the general approach to groundwater vulnerability assessment and its practical application in the context of the identification of potential groundwater pollution hazards. So far the term 'groundwater vulnerability' has dealt practically only with the issue of aquifer pollution vulnerability assessment. Recently this term has been expanded to include additional aspects, e.g. groundwater vulnerability to overexploitation, flood and drought in relation to future climate change. Wider application of geophysical techniques, modelling, statistics, isotopic investigations and tracer tests for vulnerability assessment and mapping has been recently observed. More frequently, the roles of physical and biological processes in the contaminant attenuation capacity of soil and the unsaturated zone are incorporated specifically into vulnerability assessment. Also human impact on the geological and hydrogeological environment is more often taken into account (e.g. surface and underground mining and construction activities, intensive groundwater drainage and lowering of the groundwater table, changes in geochemistry within the thicker unsaturated zone resulting in secondary groundwater contamination, and groundwater rebound due to mine or well field closures).

This interesting and successful meeting organised in the very hospitable and charming Ustron spa attracted more than 70 participants from 19 countries. The organisers received 70 abstracts and finally 59 of them, relevant to the topic of the conference, were published in the conference abstract book (Witkowski et al. 2015). Many papers were based on the results of national (e.g. Belgium, Canada, Denmark, Finland, Hungary, Italy, Ireland, Poland, Slovakia, Switzerland, UK) and international projects (e.g. COST Action 620, GENESIS, UNESCO-IHP) where the DPSIR concept and its modifications were applied. 
The scientific programme of the conference included two plenary sessions, seven thematic sessions, a poster session, a field trip and a FEFLOW course. During the plenary sessions six keynote presentations were given:

A. J. Witkowski- "Current issues in groundwater vulnerability assessment and mapping".

S. Witczak — “Groundwater vulnerability map of Poland based on time scale" (Authors: S. Witczak, A. Żurek, R. Duda, K. Różanski, and D. Kubacka).

A. Dessargues- "Sensitivity and vulnerability to groundwater overexploitation by a 'pressure state impact' and process-based approach" (Authors: J. Beaujean, J. M. Lemieux, R. Therrien, A. Dassargues, and S. Brouyère).

M. Sinreich-“Karst vulnerability assessment and validation by quantitative tracer experiments" (Authors: M. Sinreich, A. Pochon).

B. Andreo- "Preliminary proposal of guideline to delineate the protection zones of karst springs" (Authors: A. I. Marín, B. Andreo).

P. Wachniew-“A decision tree tool supporting assessment of groundwater vulnerability" (Authors: P. Wachniew, A. Żurek, Ch.Stumpp, A. Gemitzi, A. Gargini, M. Filippini, K. Różański, J. Meeks, J. Kværner, S. Witczak).

Thematic sessions focused on the following topics:

- Development of the vulnerability concept.

- Groundwater vulnerability assessment in urbanised and heavily transformed mining areas.

- Application and comparison of different methods of groundwater vulnerability assessment for different groundwater systems.

- Groundwater vulnerability and groundwater pollution risk.

- Groundwater vulnerability assessment for karstic areas.

- Groundwater vulnerability to nitrate pollution.

- Vulnerability maps in practical land-use management.

During the conference, a full-day visit to the Carpathian Mountains was organised. Topics of the tour included water management problems in mountainous regions with many domestic wells and scattered point sources of water pollution. The trip programme included a visit to the Sola River cascade system consisting of four reservoirs. Three dammed reservoirs were created along the river valley, and one (used as the upper reservoir of the pumped storage system) was built on the Żar Mountain top. In Poland, this is the first full cascade reservoir river system built according to the principle of the most efficient, comprehensive utilisation and protection of water resources. On the return, participants visited the historic brewery in Żywiec.

After extensive review and editing, ten of the most outstanding papers by international teams of authors from Denmark, Poland, Italy, Slovakia, South Africa, Germany, Czech Republic, Hungary, Serbia and Greece are being published in this topical issue of Environmental Earth Sciences.

Selected papers give an overview on some new aspects of groundwater vulnerability assessment for karstic environment (the three papers by: P. Malík, J. Švasta, J. Michalko and M. Gregor; V. Iván and J. Mádl-Szőnyi; J. Różkowski and K. Różkowski), vulnerability to nitrate pollution (the two papers by: B. Hansen, T. O. Sonnenborg, I. Møller, J. D. Bernth, A. S. Høyer, P. Rasmussen, P. Sandersen, and F. Jørgensen; M. Lasagna, D. A. De Luca and E. Franchino), groundwater pollution risk induced by historical mining activities (the one paper by: N. Atanacković, V. Dragišić, V. Živanović, S. Ninković and S. Magazinović), improving rating methods using statistical analyses (the one paper by: M. Bonfanti, D. Ducci, M. Masetti, M. Sellerino and S. Stevenazzi), comparison of different methods of groundwater vulnerability assessment (the one paper by: S. A Oke, D Vermeulen and M. Gomo), presentation of the new global map of groundwater vulnerability to floods and droughts (the one paper by: A. Richts and J. Vrba), groundwater vulnerability assessment in the context of implementation of the European Union Water Framework Directive (WFD) and Groundwater Directive (GWD) (the one paper by: Ch. Stumpp, A. Żurek, P. Wachniew, A. Gargini, A. Gemitzi, M. Filippini and S.Witczak). These papers are based on presentations made at the conference and subsequently expanded based on questions asked at the conference and additional research.

Another 15 papers will be published by Taylor \& Francis in a special volume of IAH Selected Papers.

Open Access This article is distributed under the terms of the Creative Commons Attribution 4.0 International License (http://crea tivecommons.org/licenses/by/4.0/), which permits unrestricted use, distribution, and reproduction in any medium, provided you give appropriate credit to the original author(s) and the source, provide a link to the Creative Commons license, and indicate if changes were made.

\section{References}

Różkowski A, Kowalczyk A, Motyka J, Rubin K (eds) (1996) In: International conference on karst-fractured aquifers-vulnerability and sustainability. Prace Naukowe Uniwersytetu Śląskiego w Katowicach, No 1563, 309 
Witkowski AJ (2007) Groundwater vulnerability assessment and mapping important current issues in groundwater protection. Environ Geol 53(3):477-478

Witkowski AJ, Grabala D, Wróbel J (eds) (2004) Groundwater Vulnerability assessment and mapping. In: International conference, Abstracts, Faculty of Earth Sciences, Sosnowiec, 158

Witkowski AJ, Kowalczyk A, Vrba J (eds) (2007) Groundwater vulnerability assessment and mapping. IAH Selected Papers, vol 11. Taylor \& Francis, London, p 260
Witkowski AJ, Jakóbczyk-Karpierz S, Grabala D (eds) (2015) Groundwater vulnerability-from scientific concept to practical application. In: International Conference, Ustroń, Poland. Abstracts, Sosnowiec, 82 